\title{
Research on the Impact of Financial Flexibility on Innovation Investment from the Perspective of Institutional Ownership
}

\author{
Dongping Han ${ }^{1, \mathrm{a}}, \mathrm{Jing} \mathrm{Li}{ }^{* 1, \mathrm{~b}}$,Mengwen Zhang ${ }^{1, \mathrm{c}}$ \\ ${ }^{1}$ College of Economics and Management Harbin Institute of Technology Weihai, China
}

\begin{abstract}
Uncertainty in the business environment brings many challenges and opportunities to enterprises. This paper studies the impact of financial flexibility on innovation investment from the perspective of institutional ownership, using data of A-share high-tech enterprises from 2014 to 2018 as the empirical analysis sample. The results show that financial flexibility can promote innovation investment. Moreover, compared with state-owned enterprises, cash flexibility plays a more significant role in promoting non-stateowned enterprises, while debt flexibility only promotes innovation investment in non-state-owned enterprises. Through further research, it is found that the size of institutional investors' shareholding has the positive moderating effect on the relationship between financial flexibility and innovation investment. In addition, non-independent institutional investors' shareholding plays a negative role in regulating the impact of financial flexibility on innovation investment.
\end{abstract}

\section{Introduction}

With the increasingly severe international political landscape, the economy and trade of various countries are closely linked. Facing the increasingly turbulent business environment, companies with financial flexibility can resist financial pressure to a certain extent and seize opportunities for profit. Most corporate executives around the world regard financial flexibility as one of the most important determinants of their capital structure decisions [1-3]. The innovation investment activities of high-tech enterprises have a large scale of capital investment, a long cycle, and high uncertainty in risk and output transformation. In order to ensure the normal progress of innovation investment activities in the external economic turmoil, the financial flexibility of high-tech enterprises has become more and more important. In such cases, it is critical to study how financial flexibility affects innovation investment.

At present, relevant research mainly focuses on exploring the impact of financial flexibility on investment decision-making and corporate value, and there are few studies on the impact of financial flexibility on innovation investment. Xu and Feng [4] found that R\&D investment would have a crowding-out effect on corporate general investment, leading to differences in the effects of corporate financial flexibility policies on investment in innovative activities. Xiao and Lv [5] conducted empirical studies to test that financial flexibility can ultimately improve corporate performance by enhancing innovation and investment capabilities. Wu and Guo [6] incorporated financial flexibility into the research framework of both executive overconfidence and corporate innovation investment, and found that financial flexibility had a significant positive moderating effect on the relationship between the two. Although some scholars have begun to explore the relationship between financial flexibility and corporate innovation investment, there is still a lack of direct research on how high-tech enterprise financial flexibility affects innovation investment.

Considering that the reform and opening up of the financial market makes institutional investors play an important role in the capital market and corporate governance, this paper combines institutional investors, financial flexibility and innovation investment for research, which has certain theoretical and practical significance. In terms of theory, this paper combines the theory of environmental uncertainty and the theory of financing constraints to deeply study the role of financial flexibility on the innovation investment of high-tech enterprises, enriching the research results in related fields. In terms of practice, the research results of this paper can remind companies to attach importance to the application of financial flexibility and help companies better identify the governance role played by institutional investors, so as to cope with the risks and opportunities brought by environmental changes.

\section{Theoretical Analysis and Research Hypothesis}

\subsection{Financial Flexibility and Innovation Investment}

Financial flexibility is the ability of an enterprise to take advantages of unexpected opportunities or respond to

\footnotetext{
ahandongping@hit.edu.cn

b* Corresponding author: lijinghiter@163.com

'zhangmengwen1222@126.com
} 
emergencies at low cost. Marchica and Mura [7] found that companies with financial flexibility should have more stable and better performance than other companies. The reserve of financial flexibility can help enterprises to ensure the continuous progress of innovation investment when the external environment deteriorates, and avoid the interruption of $\mathrm{R} \& \mathrm{D}$ and innovation activities that will cause huge losses to the enterprise due to funding problems. In addition, companies can use their own financial flexibility to finance the required funds at low cost from both internal and external channels, seize investment opportunities in a timely manner, increase the scale of innovation investment, and improve corporate value. Therefore, we propose hypothesis 1 :

H1: Financial flexibility promotes enterprise innovation investment.

Considering the special institutional background of China, the capital structure of enterprises with different property rights is quite different, and the degree of financing constraints and the cost of funds to get rid of financial difficulties are also significantly different. Therefore, the impact of financial flexibility on innovation investment may be different. In order to explore the differences in financial flexibility performance, this paper divides financial flexibility into cash flexibility and debt flexibility for specific analysis.

Because the cost of the company's own funds is lower than the capital cost of external financing, state-owned enterprises and non-state-owned enterprises tend to give priority to cash flexibility when making innovation investments. First, the absence of owners in state-owned enterprises makes managers pay more attention to maximizing their own interests when making financial decisions, which aggravates the agency problem. Secondly, state-owned enterprises are generally large in scale, strong in capital, and have hidden government guarantees, so they face less threat of shortage of funds. Finally, while undertaking social responsibilities and strategic burdens, state-owned enterprises have to pay certain income to the state due to their corporate nature, and their cash holdings are restricted. Considering three factors comprehensively, the promotion of innovation investment by cash flexibility may be more significant in non-state-owned enterprises.

Compared with non-state-owned enterprises, stateowned enterprises can raise funds at a lower cost in the capital market. Therefore, the leverage ratio of stateowned enterprises in operating activities is often at a higher level, and debt flexibility is difficult to play a role in innovation investment. Due to stricter financing conditions and borrowing scales, non-state-owned enterprises rely more on their good asset-liability structure, and debt flexibility can more effectively promote innovation investment.

H2: Cash flexibility and debt flexibility have different impacts on innovation investment in enterprises with different nature of property rights.

H2a: Cash flexibility promotes innovation investment in both state-owned and non-state-owned enterprises. Compared with state-owned enterprises, the promotion of innovation investment by cash flexibility is more significant in non-state-owned enterprises.
H2b: Debt flexibility has a significant role in promoting innovation investment in non-state-owned enterprises, but it has no significant effect in state-owned enterprises.

\subsection{Institutional Investors' Shareholding, Financial Flexibility and Innovation Investment}

Institutional investors have unparalleled advantages over ordinary retail investors [8]. According to "shareholder activism", institutional investors can effectively restrain the agency issues of management through their own advantages and play an important role in the corporate governance structure. Aghion, Van, and Zingales [9] found that institutional investors can improve innovation capabilities by reducing managers' professional risks. Studies have shown that institutional investors' efforts to influence corporate decisions depend on the number of shares they hold. If institutional investors hold a large number of shares, have a low turnover rate, or hold them for a long time, they are more motivated to regulate corporate management behaviors [10]. According to the "principle-agent problem" and "information asymmetry problem" that may arise when implementing the financial flexibility policy, combined with the performance of institutional investors holding shares in participating in corporate governance [11], we propose:

H3: The size of institutional investors' shareholding has the positive moderating effect on the relationship between financial flexibility and innovation investment.

Different types of institutional investors may play different roles in stabilizing the market. In this paper, institutional investors are divided into independent institutional investors and non-independent institutional investors according to their relationship with listed companies and whether they are stable value investments. Independent institutional investors generally do not have commercial ties with companies other than investment, which helps to improve the level of corporate governance, and changes in the holding behavior of such institutional investors are more likely to send positive signals to the market. There are more complicated interest relationships among non-independent institutional investors, and it is difficult to limit the inefficient behavior of managers. Therefore, we propose:

H4: Different types of institutional investors' shareholding have different moderating effects between financial flexibility and innovation investment.

H4a: Independent institutional investors' shareholding has the positive moderating effect between financial flexibility and innovation investment.

H4b: Non-independent institutional investors' shareholding has the negative moderating effect between financial flexibility and innovation investment.

\section{Research Design}

\subsection{Data Collection}

This paper selected the continuous data of China's A-share high-tech companies from 2014 to 2018 as the empirical 
analysis sample. The independent variables lagged one period to reduce the endogenous problems of the model. The calculation of the dependent variable used the total assets at the end of the previous period, and the actual sample data year range was 2013-2018. The selection of data was based on the following principles: (1) exclude the financial industry; (2) exclude ST companies; (3) exclude the missing samples in the CSMAR database; (4) exclude firms that do not have continuous data from 2014-2018.

After screening, we obtained 7190 samples from 1438 enterprises in 16 industries during 2014-2018 from the CSMAR database. In this paper, STATA15.0 was used to analyze the sample data.

\subsection{Models and Variables}

Following previous studies, we constructed the following models to test the impact of corporate financial flexibility on innovation investment.

\subsubsection{The Impact of Financial Flexibility on Innovation Investment}

In order to explore the role of financial flexibility in promoting innovation investment, model 1 was constructed.

$$
\begin{aligned}
R D_{i, t} & =a_{0}+a_{1} F F_{i, t-1}+a_{2} \operatorname{SIZE}_{i, t}+a_{3} F X_{i, t}+a_{4} G R O W \\
& +a_{5} T O P_{i, t}+a_{6} S O E+\sum I N D+\sum Y E A R+\varepsilon_{i, t}
\end{aligned}
$$

The dependent variable RD refers to the company's innovation investment. Innovation investment (RD) is mainly research and development investment. In order to eliminate the influence of factors such as enterprise scale, the innovation investment in this paper is equal to the enterprise $R \& D$ investment this year divided by the total assets at the beginning. The independent variable FF refers to the overall financial flexibility of the enterprise. Overall financial flexibility (FF) is measured by the sum of cash flexibility and debt flexibility.

In order to further study the impact of financial flexibility on innovation investment in enterprises with different property rights, this paper divides financial flexibility into cash flexibility and debt flexibility, and establishes the following models to verify $\mathrm{H} 2$.

$$
\begin{aligned}
R D_{i, t} & =a_{0}+a_{1} C F_{i, t, 1}+a_{2} S I Z E_{i,,+}+a_{3} F X_{i,+}+a_{4} G R O W \\
& +a_{s} \text { TOP } P_{i, t}+\sum I N D+\sum \text { YEAR }+\varepsilon_{i,,}
\end{aligned}
$$

$$
\begin{aligned}
R D_{i, t} & =a_{0}+a_{1} D F_{i, t-1}+a_{2} S I Z E_{i,,}+a_{3} F X_{i, t}+a_{4} G R O W_{i,,} \\
& +a_{5} T O P_{t, t}+\sum I N D+\sum Y E A R+\varepsilon_{i, t}
\end{aligned}
$$

We divided the sample into two groups of state-owned enterprises and non-state-owned enterprises according to the nature of property rights, and used cash flexibility (CF) and debt flexibility (DF) as independent variables for regression.

\subsubsection{Moderating Effect of Institutional Investors' Shareholding}

In order to explore the role of institutional investors' shareholding in the relationship between financial flexibility and innovation investment, the following models were established.

We established Model 4 to explore the impact of the size of institutional investors' shareholding on the relationship between financial flexibility and innovation investment.

$$
\begin{aligned}
R D_{t, t} & =a_{0}+a_{1} F F_{t, t-1}+a_{2} I N S_{t, t}+a_{3} F F_{t, t-1} * I N S_{t, t}+a_{4} S I Z E_{b, t}+a_{s} F X_{t, t} \\
& +a_{6} G R O W W_{l, t}+a_{1} T O P_{t, t}+a_{s} S O E+\sum I N D+\sum Y E A R+\varepsilon_{l, t}
\end{aligned}
$$

In the model, INS refers to the size of institutional investors' shareholdings, and FF*INS refers to the interaction term of institutional investors' total shareholdings (INS) and financial flexibility (FF). We can verify the moderating effect through the coefficient and significance of the interaction term.

Institutional investors disclosed in the CSMAR database include funds, social security funds, QFII, banks, securities companies, insurance companies, trust companies, and financial companies. Among them, funds, social security funds and QFII are independent institutional investors, and the others are non-independent institutional investors. In order to further study the impact of institutional investor heterogeneity, we divided institutional investors into independent institutional investors and non-independent institutional investors, and established the following models.

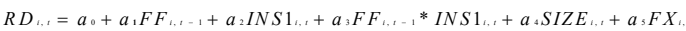

$$
\begin{aligned}
& +a_{6} G R O W_{1,+}+a_{7} T O P_{,,+}+a_{*} S O E+\sum I N D+\sum Y E A R+\varepsilon \\
& R D_{i, t}=a_{0}+a_{1} F F_{t,+-1}+a_{2} I N S 2_{i, t}+a_{3} F F_{t,+,-1} * I N S 2_{i, t}+a_{4} S I Z E_{t, t}+a_{5} F X_{t,} \\
& +a_{6} G R O W_{i, t}+a_{7} T O P_{i, t}+a_{8} S O E+\sum I N D+\sum Y E A R+\varepsilon_{t,}
\end{aligned}
$$

\begin{tabular}{|c|c|c|c|}
\hline $\begin{array}{l}\text { Variable } \\
\text { category }\end{array}$ & Variable name & $\begin{array}{c}\text { Variable } \\
\text { symbol }\end{array}$ & Variable definitions \\
\hline $\begin{array}{c}\text { Dependent } \\
\text { variable }\end{array}$ & Innovation Investment & $\mathrm{RD}$ & R\&D investment/ Total assets at the beginning of the year \\
\hline \multirow{3}{*}{$\begin{array}{c}\text { Independent } \\
\text { variable }\end{array}$} & Financial Flexibility & FF & Cash flexibility + Debt flexibility \\
\hline & Cash Flexibility & $\mathrm{CF}$ & Corporate cash assets to ratio - Industry average cash to assets ratio \\
\hline & Debt Flexibility & DF & $\operatorname{Max}(0$, industry average debt to assets ratio - enterprise debt to assets ratio) \\
\hline \multirow{2}{*}{$\begin{array}{c}\text { Moderator } \\
\text { variables }\end{array}$} & $\begin{array}{c}\text { Size of Institutional } \\
\text { Investors' Shareholdings }\end{array}$ & INS & Sum of institutional shareholdings / (Tradable shares + Non-tradable shares) \\
\hline & $\begin{array}{c}\text { Size of Independent } \\
\text { Institutional Investors } \\
\text { Shareholdings }\end{array}$ & INS1 & Sum of independent institutional shareholding / (Tradable shares + Non-tradable shares) \\
\hline
\end{tabular}

In the models, INS1 refers to the size of independent institutional investors' shareholding, while INS2 refers to the size of non-independent institutional investors' shareholding.

The definitions of variables are shown in Table 1.

Table1. Variable Definitions 


\begin{tabular}{|c|c|c|c|}
\hline $\begin{array}{l}\text { Variable } \\
\text { category }\end{array}$ & Variable name & $\begin{array}{c}\text { Variable } \\
\text { symbol }\end{array}$ & Variable definitions \\
\hline & $\begin{array}{l}\text { Size of Non-independent } \\
\text { Institutional Investors' } \\
\text { Shareholdings }\end{array}$ & INS2 & $\begin{array}{c}\text { Sum of non-independent institutional shareholding / (Tradable shares + Non-tradable } \\
\text { shares) }\end{array}$ \\
\hline \multirow{7}{*}{$\begin{array}{c}\text { Control } \\
\text { variables }\end{array}$} & Scale of Listed Company & SIZE & Ln (total assets at the beginning of the year) \\
\hline & Fixed Assets Ratio & FX & Net fixed assets/ Total Assets \\
\hline & $\begin{array}{l}\text { Growth Rate of Total } \\
\text { Operating Revenue }\end{array}$ & GROW & $\begin{array}{l}\text { (Total operating revenue in current period - Total operating revenue in the same period of } \\
\text { previous year) / (Total operating revenue in the same period of previous year) }\end{array}$ \\
\hline & Ownership Concentration & TOP & Shareholding percentage of the largest shareholder \\
\hline & Nature of Property Right & SOE & 1 for state-owned enterprises and 0 for non-state-owned enterprises \\
\hline & Industry & IND & $\begin{array}{c}\text { Classification is based on "China Securities Regulatory Commission Industry Classification } \\
2012 \text { Edition". } \\
\text { Industry Dummy Variable }\end{array}$ \\
\hline & Year & YEAR & Annual Dummy Variable \\
\hline
\end{tabular}

\section{Results}

\subsection{Descriptive statistics}

Table 2 shows the descriptive statistics of the variables. According to the statistical results, the average value of innovation investment in high-tech enterprises is $4.949 \%$, and there is a large difference between the maximum value and the minimum value, indicating that the level of innovation investment of different enterprises is very different. The maximum value of financial flexibility is $69.120 \%$, and the minimum value is $-14.130 \%$, indicating that the level of financial flexibility of different enterprises is also very different. The average shareholding scale of institutional investors is $7.146 \%$, and there is a big difference between the maximum value and the minimum value, that is, the shareholding situation of institutional investors in various companies is quite different. It is worth noting that the average shareholding ratio of independent institutional investors is $4.847 \%$, which is significantly larger than the $2.254 \%$ shareholding ratio of non-independent institutional investors. This shows that in the current Chinese capital market, the shareholding ratio of independent institutional investors in high-tech enterprises is significantly higher than that of nonindependent institutional investors.

On the whole, the sample data distribution is relatively even, and the standard deviation of each variable is relatively small. This shows that the sample data is relatively stable and can be analyzed in depth.
Table2. Descriptive Statistics

\begin{tabular}{|c|c|c|c|c|}
\hline Variable & Mean & SD & Maximum & Minimum \\
\hline RD & 4.949 & 0.045 & 26.680 & 0.100 \\
\hline FF & 8.367 & 0.178 & 69.120 & -14.130 \\
\hline CF & 0.463 & 0.111 & 40.940 & -15.470 \\
\hline DF & 7.886 & 0.101 & 34.440 & 0.000 \\
\hline SIZE & 22.250 & 0.012 & 25.950 & 20.140 \\
\hline FX & 20.590 & 0.135 & 60.730 & 0.726 \\
\hline GROW & 19.650 & 0.401 & 244.600 & -44.800 \\
\hline TOP & 32.020 & 0.136 & 69.280 & 8.348 \\
\hline INS & 7.146 & 0.064 & 28.300 & 0.001 \\
\hline INS1 & 4.847 & 0.054 & 24.640 & 0.000 \\
\hline INS2 & 2.254 & 0.032 & 16.460 & 0.000 \\
\hline
\end{tabular}

\subsection{Regression Analysis}

\subsubsection{The Impact of Financial Flexibility on Innovation Investment}

Table 3 shows the regression results of Model 1, 2 and 3. Because the $p$ value of the Hausman test is less than 0.01, the fixed-effects model is used for regression analysis in Model 1. The regression coefficient of financial flexibility in Model 1 is 0.049 , and $\mathrm{P}<0.01$, indicating that the financial flexibility of high-tech enterprises can significantly promote enterprise innovation investment. $\mathrm{H} 1$ is verified.

Table3. Variable Regression Coefficients of Model 1, 2 and 3

\begin{tabular}{|c|c|c|c|c|c|}
\hline \multirow{2}{*}{ Variable } & Model 1 & Model 2 & Model 2 & Model 3 & Model 3 \\
\cline { 2 - 6 } & & $\boldsymbol{S O E}=\mathbf{1}$ & $\boldsymbol{S O E}=\mathbf{0}$ & $\boldsymbol{S O E}=\mathbf{1}$ & $\boldsymbol{S O E}=\mathbf{0}$ \\
\cline { 2 - 6 } & $\boldsymbol{R D}$ & $\boldsymbol{R D}$ & $\boldsymbol{R D}$ & $\boldsymbol{R D}$ & $\boldsymbol{R D}$ \\
\hline FF & $0.049^{* * *}$ & & & & \\
\hline $\mathrm{CF}$ & & $0.036^{* * *}$ & $0.058^{* * * *}$ & & \\
\hline $\mathrm{DF}$ & & & & 0.050 & $0.091^{* * *}$ \\
\hline $\mathrm{SIZE}$ & $-0.315^{* * *}$ & $-0.336^{* * *}$ & $-0.590^{* * *}$ & $-0.252^{* * *}$ & $-0.296^{* * *}$ \\
\hline
\end{tabular}




\begin{tabular}{|c|c|c|c|c|c|}
\hline \multirow{3}{*}{ Variable } & Model 1 & Model 2 & Model 2 & Model 3 & Model 3 \\
\hline & & $S O E=1$ & $S O E=0$ & $S O E=1$ & $S O E=0$ \\
\hline & $R D$ & $R D$ & $R D$ & $R D$ & $R D$ \\
\hline $\mathrm{FX}$ & $-0.030 * * *$ & $-0.032 * * *$ & $-0.035^{* * *}$ & $-0.038 * * *$ & $-0.041 * * *$ \\
\hline GROW & $-0.009 * * *$ & -0.002 & $-0.011 * * *$ & -0.002 & $-0.012 * * *$ \\
\hline TOP & $-0.023 * * *$ & $-0.022 * * *$ & $-0.019 * * *$ & $-0.021 * * *$ & $-0.019 * * *$ \\
\hline Constant & $10.947 * * *$ & $12.510 * * *$ & $16.609 * * *$ & $10.639 * * *$ & $9.935^{* * *}$ \\
\hline YEAR & Control & Control & Control & Control & Control \\
\hline IND & Control & Control & Control & Control & Control \\
\hline Observations & 7190 & 2135 & 5055 & 2135 & 5055 \\
\hline $\mathrm{R}^{2}$ & 0.286 & 0.187 & 0.276 & 0.188 & 0.291 \\
\hline $\mathrm{F}$ & 116.4 & 23.28 & 84.79 & 23.53 & 91.40 \\
\hline
\end{tabular}

In Model 2, the regression coefficients of cash flexibility in state-owned enterprises and non-state-owned enterprises are both positive $(p<0.01)$. This shows that cash flexibility promotes innovation investment in both state-owned and non-state-owned enterprises. In order to study whether there is a difference in the promotion effect of cash flexibility between the two groups of samples, we used the SUEST model to test the difference in coefficients between groups. The results in Table 4 show that there are differences in the regression coefficients of cash flexibility between the two groups in Model 2, and the differences are significant. The coefficient of financial flexibility of non-state-owned enterprises is 0.058 , which is greater than the regression coefficient of state-owned enterprises of 0.036 , indicating that cash flexibility can more effectively promote innovation investment in nonstate-owned enterprises. H2a is supported.

In Model 3, the regression coefficient of liability flexibility in the Chinese state-owned enterprise group was 0.050 , which failed the significance test, while the regression coefficient of cash flexibility and innovation investment in the non-state-owned enterprise group was 0.091 , which passed the significance test $(p<0.01)$. The results show that debt flexibility has a significant role in promoting innovation investment in non-state-owned enterprises, but it has no significant effect in state-owned enterprises. $\mathrm{H} 2 \mathrm{~b}$ is verified.

Table4. SUEST Test

\begin{tabular}{|c|c|c|}
\hline Model name & Chi-Sq.CF & Prob \\
\hline Model 2 & 3.30 & 0.0694 \\
\hline
\end{tabular}

Table5. Variable Regression Coefficients of Model 4, 5 and 6

\begin{tabular}{|c|c|c|c|}
\hline \multirow{2}{*}{ Variable } & Model 4 & Model 5 & Model 6 \\
\cline { 2 - 4 } & & Independent & $\begin{array}{c}\text { Non- } \\
\text { independent }\end{array}$ \\
\cline { 2 - 4 } & $\boldsymbol{R D}$ & $\boldsymbol{R D}$ & $\boldsymbol{R D}$ \\
\hline FF & $0.085^{* * *}$ & $0.044^{* * *}$ & $0.056^{* * *}$ \\
\hline INS & 0.011 & & \\
\hline FFINS & $0.021^{* * *}$ & & \\
\hline
\end{tabular}

\begin{tabular}{|c|c|c|c|}
\hline \multirow{2}{*}{ Variable } & Model 4 & Model 5 & Model 6 \\
\cline { 2 - 4 } & & Independent & $\begin{array}{c}\text { Non- } \\
\text { independent }\end{array}$ \\
\cline { 2 - 4 } & $\boldsymbol{R D}$ & $\boldsymbol{R D}$ & $\boldsymbol{R D}$ \\
\hline INS1 & & $0.061^{* * *}$ & \\
\hline INS2 & & & $-0.054 * * *$ \\
\hline FFINS1 & & 0.011 & \\
\hline FFINS2 & & & $-0.030^{* *}$ \\
\hline SIZE & $-0.353^{* * *}$ & $-0.377^{* * *}$ & $-0.266^{* * *}$ \\
\hline FX & $-0.034 * * *$ & $-0.029 * * *$ & $-0.030^{* * *}$ \\
\hline GROW & $-0.009 * * *$ & $-0.009 * * *$ & $-0.009 * * *$ \\
\hline TOP & $-0.032 * * *$ & $-0.021 * * *$ & $-0.024 * * *$ \\
\hline Constant & $12.334 * * *$ & $11.821^{* * *}$ & $9.984 * * *$ \\
\hline YEAR & Control & Control & Control \\
\hline IND & Control & Control & Control \\
\hline Observations & 7190 & 7190 & 7190 \\
\hline R ${ }^{2}$ & 0.312 & 0.284 & 0.283 \\
\hline F & 63.45 & 101.4 & 101.1 \\
\hline
\end{tabular}

Note: *,** and $* * *$ denote statistical significance at the $10 \%, 5 \%$ and $1 \%$ level respectively.

\subsubsection{Moderating Effect of Institutional Investors' Shareholding}

Table 5 shows the test results of Model 4, 5 and 6. In Model 4, the coefficient of FFINS is 0.021 , reaching $1 \%$ significance level. This shows that the size of institutional investors' shareholding has the positive moderating effect on the relationship between financial flexibility and innovation investment. $\mathrm{H} 3$ is proved.

In Model 5, the coefficient of the interaction term FFINS1 is 0.011 , which fails the significance test, so H4a is not verified. In Model 6, the coefficient of the interaction term FFINS2 is -0.030 with a significance level of $1 \%$. It means that non-independent institutional investors have the negative moderating effect between financial flexibility and innovation investment. $\mathrm{H} 4 \mathrm{~b}$ is supported. 


\subsection{Robust Test}

Since the proportion of R\&D investment in operating income is often used to measure corporate innovation investment, this paper uses the proportion of $R \& D$ investment in operating income as the dependent variable to regress the models again. From the results, the significance levels of independent variables, regulatory variables, and control variables are not significantly different from the original results, and the regression coefficients of the variables have not fundamentally changed, indicating that the results are robust.

\section{Conclusions}

This paper studies the impact of the financial flexibility of high-tech enterprises on innovation investment from the perspective of institutional ownership. The results show that the financial flexibility of high-tech enterprises can promote innovation investment; compared with stateowned enterprises, the promotion of innovation investment by cash flexibility is more significant in nonstate-owned enterprises, while debt flexibility only promotes innovation investment in non-state-owned enterprises. In addition, differences in size and type of shareholding can affect the governance role of institutional investors. The size of institutional investors' shareholding has the positive moderating effect on the relationship between financial flexibility and innovation investment. Non-independent institutional investors' shareholding plays a negative role in regulating the impact of financial flexibility on innovation investment.

This paper adds institutional investors to the research on the relationship between corporate financial flexibility and innovation investment, and deeply explores the moderating effect of institutional investors' shareholding. This research has enriched the literature related to the economic consequences of corporate financial flexibility and corporate innovation. It is conducive to high-tech enterprises to increase the awareness of reserving financial flexibility, strengthen the optimization of corporate governance structure, and seize innovation opportunities.

\section{Acknowledgment}

This paper was supported by National Natural Science Foundation of China (Grant No. 71672046).

\section{References}

1. J. R. Graham, and C. R. Harvey, "The Theory and Practice of Corporate Finance: Evidence from the Field," SSRN Electronic Journal, vol. 60, pp. 187-243, 1999.

2. F. Bancel, and U. R. Mittoo, "Cross-country determinants of capital structure choice: a survey of European firms," Financial Management, vol. 33, pp. 103-132, 2004.

3. D. Brounen, A. De Jong, and K. Koedijk, "Capital Structure Policies in Europe: Survey Evidence,"
Journal of Banking and Finance, vol. 30, pp. 14091442, 2006.

4. L. Xu, and Q. G. Feng, "Financial Flexibility Policy Choice and R\&D Investment-Based on the Research of GEM Listed Companies," Contemporary Finance \& Economics, no. 09, pp. 110-120, 2015.

5. J. B. Xiao, and S. Lv, "Financial Flexibility, R\&D Investment and Company Performance-Based on Empirical Data of Listed Companies in the High-tech Industry," Finance and Accounting Monthly, no. 36, pp. 20-24, 2015.

6. X. J. Wu, and S. J. Guo, "Financial Flexibility, Executive Overconfidence and Investment in Technological Innovation," Enterprise Economy, vol. 35, no. 11, pp. 35-40, 2016.

7. M. Marchica, and R. Mura, "Financial Flexibility, Investment Ability, and Firm Value: Evidence from Firms with Spare Debt Capacity," Financial Management, vol. 39, no. 4, pp. 1339-1365, 2010.

8. Q. J. Pan, and X. N. Li, "Managerial Competence, Institutional Investors and Corporate Overinvestment", Modern Management Science, no. 3, pp. 106-108, 2016.

9. P. Aghion, R. Van, and L. Zingales, "Innovation and Institutional ownership," American Economic Review, vol. 103, pp. 277-304, 2013.

10. S. Wahal, and J. McConnell, "Do Institutional Investors Exacerbate Managerial Myopia?" Journal of Corporate Finance, vol. 6, no. 3, pp. 307-329, 2000.

11. J. B. Qi, and T. L. An, "Institutional Investor Shareholding and Corporate R\&D InvestmentBased on the Consideration of Nonlinearity and Heterogeneity," China Economic Studies, no. 03, pp. 29-41, 2014. 